\title{
Tocilizumab for treating COVID-19: a systemic review and meta-analysis of retrospective studies
}

\author{
Meng Zhao ${ }^{1} \cdot$ Jieyu $\mathrm{Lu}^{2} \cdot$ Yihu Tang ${ }^{1} \cdot$ Yawei Dai $^{1} \cdot$ Jingxin Zhou ${ }^{1} \cdot$ Yanhu Wu ${ }^{1}$
}

Received: 13 August 2020 / Accepted: 7 October 2020 / Published online: 13 October 2020

(C) Springer-Verlag GmbH Germany, part of Springer Nature 2020

\begin{abstract}
Objectives COVID-19 has become a global epidemic, and effective therapies have not been discovered up to now. We conducted this study to explore the effectiveness and safety of tocilizumab recently used for treating COVID-19.

Method A comprehensive search was conducted (up to September 27, 2020), and 19 eligible records were identified according to the inclusion and exclusion criteria. The data of the studies were extracted by 2 independent reviewers and were analyzed to evaluate the safety and availability of tocilizumab for treating COVID- 19.

Results Thirteen retrospective case-control studies $(n=2285$ patients) and 6 retrospective single-armed studies $(n=208)$ were retrieved in this study. In the comparison of tocilizumab treatment group (TCZ) and standard treatment group (ST), significant associations with a lower risk of admission to ICU, use of ventilation, and mortality (OR, 95\% CI: 0.53, 0.26 1.09; 0.66, $0.46 \sim 0.94 ; 0.44,0.36 \sim 0.55$ ) were found in the tocilizumab treatment group. What is more, patients treated with tocilizumab had better clinical improvement compared with the patients treated with ST (OR, 1.24; 95\% CI, 0.96 1.62). After taking tocilizumab, the patients had lower C-reactive protein (CRP), white blood cell count (WBC), aspartate aminotransferase (AST) (WMD, 95\% CI: - 99.66, - 156.24 - 43.09; - 0.95, -1.8 - 0.11; - 12.58, - 18.88 -6.29) but higher troponin (WMD, 7.61; 95\% CI, 3.06 12.15) than before. In addition, tocilizumab did not have significant influence on patients' neutrophil count (Neut), lymphocyte count (Lymp), platelet count (Plt), alanine aminotransferase (ALT), and creatine (WMD, 95\% CI: $0.29,-2.91 \sim 2.33 ; 0.42,-0.23 \sim 1.07 ; 5.2,-2.85 \sim 13.25 ; 22.49,-2.73 \sim 47.7 ;-44.78,-93.37 \sim 3.81)$.

Conclusion Tocilizumab may have potential effectiveness to treat COVID-19 according to the results of this study. However, more large-scale studies are needed for more accurate conclusions.
\end{abstract}

Keywords Tocilizumab $\cdot$ IL-6 blockade $\cdot$ COVID-19 $\cdot$ Meta-analysis

Electronic supplementary material The online version of this article (https://doi.org/10.1007/s00228-020-03017-5) contains supplementary material, which is available to authorized users.

Jingxin Zhou

jingxin110@sina.com

Yanhu $\mathrm{Wu}$

wuyanhu@njmu.edu.cn

1 Department of Cardiovascular Surgery, The First Affiliated Hospital of Nanjing Medical University, Nanjing 210029, Jiangsu Province, China

2 Department of Cardiology, the First Affiliated Hospital of Nanjing Medical University, Nanjing, Jiangsu, China

\section{Introduction}

Since December 2019, the global epidemic of novel coronavirus disease 2019 (COVID-19) had infected over 30,000,000 people worldwide up to September 27, 2020. COVID-19 can result in interstitial pneumonia with respiratory failure, which is the principal cause of death [1]. There is no widely approved medicine for treating this deadly infectious disease as yet.

In recent months, several case reports or case series [2-5] indicated that interleukin- 6 receptor antagonist tocilizumab successfully improved the clinical manifestations of sever patients infected by COVID-19. There were also several retrospective case-control and single-armed studies that reported the outcomes of using tocilizumab for treating COVID-19. However, the results of those studies have not been systemically reviewed and analyzed. Thus, we collected and 
summarized those studies to explore the effectiveness and safety of tocilizumab recently used for treating COVID-19.

\section{Materials and methods}

\section{Literature search}

A comprehensive search using (tocilizumab) OR (anti-IL-6 monoclonal antibody) OR (IL-6 blockade) OR (IL-6 receptor antagonist) AND (COVID-19) OR (novel coronavirus disease) OR (SARS-CoV-2) was conducted by 2 authors using PubMed, Embase, Medline, and Cochrane (up to September 27, 2020), and the language was limited to English.

\section{Selection criteria}

The studies searched in three databases were included by the following criteria: (1) patients had a definite diagnosis of COVID-19 infection; (2) patients received tocilizumab treatment; and (3) sufficient data were provided for clinical outcomes. Additionally, unqualified studies were excluded by the following criteria: (1) case reports, reviews, editorials, and letters; (2) duplicate records; and (3) studies with insufficient data.

\section{Data extraction and quality assessment}

Two authors extracted necessary information from each included study: first author, publication year, sample size, gender, clinical outcomes of TCZ group, ST group, and pre-TCZ and post-TCZ. The quality of each study was not assessed because of the extremely insufficiency of data of the included studies.

\section{Statistical analysis}

In the retrospective case-control studies, odds ratios (ORs) of admission to ICU, use of ventilation, mortality, and clinical improvement were calculated to compare the effectiveness between tocilizumab treatment and standard treatment.

In the retrospective single-armed studies, weighted mean differences (WMDs) of CRP, procalcitonin, WBC count, AST, troponin, Neut count, Lymp count, Plt count, ALT, and creatine were compared between pre-TCZ and post-TCZ to assess the safety of tocilizumab on the blood system, inflammatory reaction, heart, liver, and kidney.

Formula $\mathrm{SD} \approx$ Norm $\mathrm{IQR}=\left(\mathrm{P}_{75-}-\mathrm{P}_{25}\right) \times 0.7413$ [6] was used to calculate the $\mathrm{SD}$ of the outcomes.

The heterogeneity of the results was estimated using the Q test and $I^{2}$ statistics. The fixed pooling model was used when $I^{2} \leq 50 \%$; otherwise, the random pooling model was selected.
WMD $<0$ suggested a decrease in indicator after taking tocilizumab. OR $<1$ indicated favorable outcomes of admission to ICU, use of ventilation, and mortality but poor clinical improvement in TCZ group. These calculations were completed using Stata v.16.

\section{Results}

\section{Characteristics of the included studies}

The procedures used to screen eligible studies are shown in Fig. 1. Nineteen articles with 2493 patients were included. The details of the 19 included studies are summarized in Table 1, and all the calculated outcomes are shown in Table 2.

\section{TCZ VS ST}

Thirteen studies and 2285 patients were included to compare the outcomes between TCZ and ST groups. The ORs for admission to ICU, use of ventilation, mortality, and clinical improvement between TCZ and ST were shown in Fig. 2 and Fig. 3. Lower rate of admission to ICU, use of ventilation, and mortality and higher rate of clinical improvement were identified in the TCZ group.

\section{Changes of clinical indicators after taking tocilizumab}

After taking tocilizumab, the value of CRP significantly decreased (Fig. 4). In the blood system, the WBC count, Neut count, Lymp count, and Plt count were not obviously influenced by tocilizumab (Fig. 5). In addition, Fig. 6 showed that the value of AST significantly decreased and troponin increased after taking tocilizumab. However, the level of ALT and creatine were not significantly affected.

\section{Sensitivity analysis}

Sensitivity analysis of the OR for mortality between the TCZ and ST groups was calculated to evaluate the robustness of the results. Figure 7 indicates that the results would not be obviously changed by deleting any included study.

\section{Discussion}

Pneumonia is the most common clinical manifestation of COVID-19 infection, and 6-10\% of the patients can evolve into respiratory failure, requiring mechanical ventilation or positive airway pressure therapy [26]. Dawei Wang [27] reported that the acute respiratory distress syndrome (ARDS) caused by COVID-19 may have associations with cytokine storm syndrome. Fei Zhou [28] also 
Fig. 1 PRISMA flow diagram of procedures used to screen eligible studies
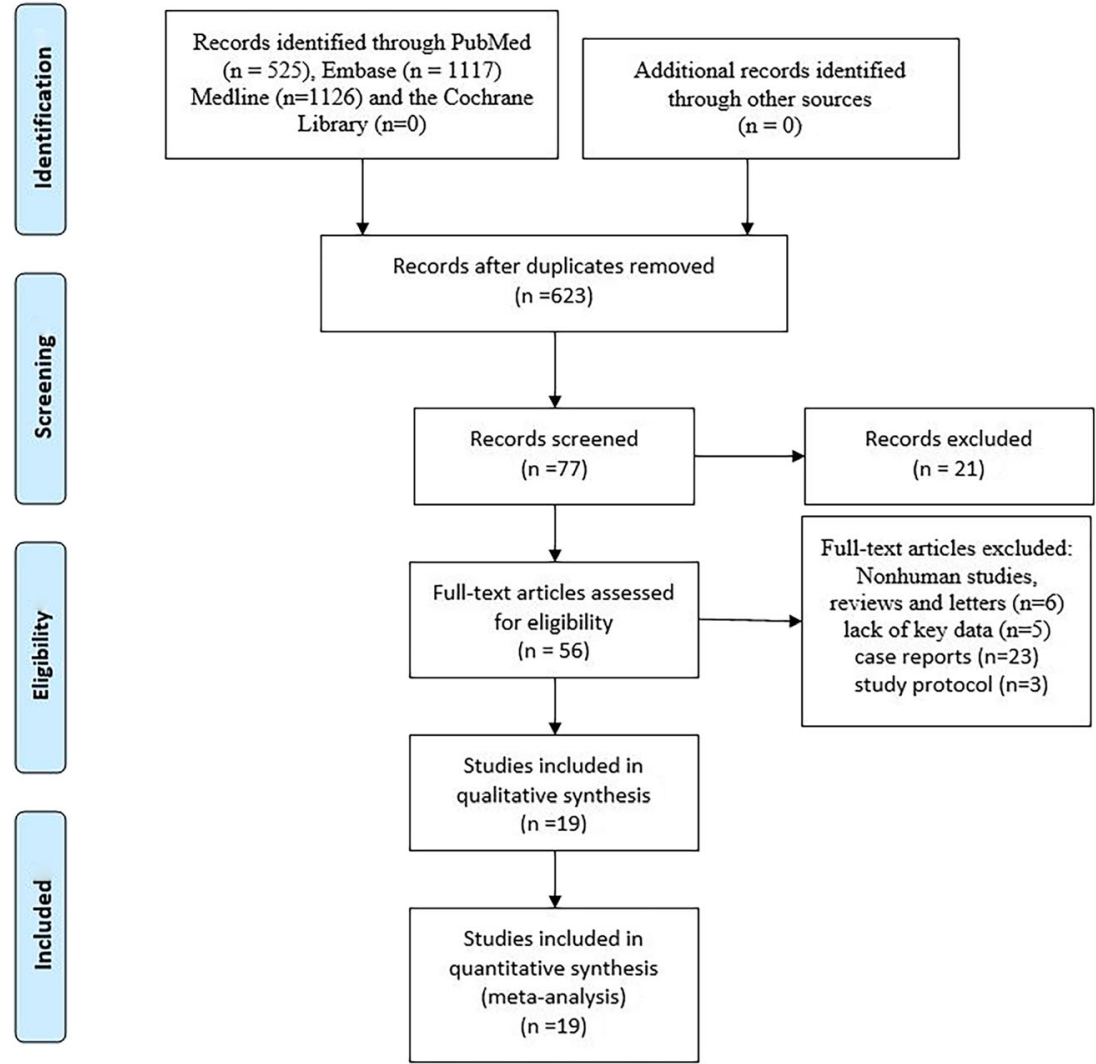

reported that higher IL-6 was associated with more frequency mortality. Therefore, tocilizumab, as the IL-6 receptor antagonist, is used for treating COVID-19 in more and more therapeutic centers. Until now, studies

Table 1 Characteristics of the included studies

\begin{tabular}{|c|c|c|c|c|c|}
\hline First author & Year & Sample size & Sex (male \%) & Study type & Comparison \\
\hline Corrado Campochiaro [7] & 2020 & 65 & 86.15 & Retrospective case-control study & TCZ group VS ST group \\
\hline Ruggero Capra [8] & 2020 & 85 & $75 \%$ & Retrospective case-control study & TCZ group VS ST group \\
\hline Luca Quartuccio [9] & 2020 & 111 & $78.60 \%$ & Retrospective case-control study & TCZ group VS ST group \\
\hline Marta Colaneri [10] & 2020 & 111 & $73.21 \%$ & Retrospective case-control study & TCZ group VS ST group \\
\hline Timothée Klopfenstein [11] & 2020 & 45 & NA & Retrospective case-control study & TCZ group VS ST group \\
\hline Mar Masia [12] & 2020 & 138 & $61.6 \%$ & Retrospective case-control study & TCZ group VS ST group \\
\hline Laetitia Albertini [13] & 2020 & 44 & $70.5 \%$ & Retrospective case-control study & TCZ group VS ST group \\
\hline Noa Biran [14] & 2020 & 630 & $69.2 \%$ & Retrospective case-control study & TCZ group VS ST group \\
\hline Giovanni Guaraldi [15] & 2020 & 544 & $66 \%$ & Retrospective case-control study & TCZ group VS ST group \\
\hline Tariq Kewan [16] & 2020 & 65 & $61 \%$ & Retrospective case-control study & TCZ group VS ST group \\
\hline Lorenzo M. Canziani [17] & 2020 & 128 & $73 \%$ & Retrospective case-control study & TCZ group VS ST group \\
\hline Yojana Gokhale [18] & 2020 & 161 & $62.1 \%$ & Retrospective case-control study & TCZ group VS ST group \\
\hline Nicola De Rossi [19] & 2020 & 158 & 71.5 & Retrospective case-control study & TCZ group VS ST group \\
\hline Xiaoling Xu [20] & 2020 & 21 & $85.70 \%$ & Retrospective single-armed study & Pre-TCZ VS post-TCZ \\
\hline Nahéma Issa [21] & 2020 & 10 & NA & Retrospective single-armed study & Pre-TCZ VS post-TCZ \\
\hline Rand Alattar [22] & 2020 & 25 & $92 \%$ & Retrospective single-armed study & Pre-TCZ VS post-TCZ \\
\hline Paola Toniati [23] & 2020 & 100 & $88 \%$ & Retrospective single-armed study & Pre-TCZ VS post-TCZ \\
\hline Betul Borku Uysal [24] & 2020 & 12 & $50 \%$ & Retrospective single-armed study & Pre-TCZ VS post-TCZ \\
\hline Muhammad Zain Mushtaq [25] & 2020 & 40 & $82.5 \%$ & Retrospective single-armed study & Pre-TCZ VS post-TCZ \\
\hline
\end{tabular}

TCZ, tocilizumab; ST, standard treatment; NA, not accessible 
Table 2 Clinical outcomes of using tocilizumab

TCZ group and ST group

\begin{tabular}{|c|c|c|c|c|c|}
\hline Outcomes & $\begin{array}{l}\text { Numbers of included studies } \\
\text { (sample size) }\end{array}$ & OR & $95 \% \mathrm{CI}$ & $I^{2}$ & $p$ value \\
\hline Admission to ICU & $3(295)$ & 0.53 & $(0.26,1.09)$ & $65.5 \%$ & 0.055 \\
\hline Use of ventilation* & $6(911)$ & 0.66 & $(0.46,0.94)$ & $73.1 \%$ & 0.002 \\
\hline Mortality*** & $13(2227)$ & 0.44 & $(0.36,0.55)$ & $69.1 \%$ & $<0.001$ \\
\hline $\begin{array}{l}\text { Clinical improvement } \\
\text { Pre-TCZ and post-TCZ }\end{array}$ & $6(996)$ & 1.24 & $(0.96,1.62)$ & $48.8 \%$ & 0.082 \\
\hline Outcomes & Numbers of included studies (sample size) & WMD & $95 \%$ CI & $I^{2}$ & $p$ value \\
\hline $\mathrm{CRP}(\mathrm{mg} / \mathrm{L}) * * *$ & $5(196)$ & -99.66 & $(-156.24,-43.09)$ & $96.2 \%$ & $<0.001$ \\
\hline WBC count $\left(10^{\wedge} 9 / \mathrm{L}\right) *$ & $3(57)$ & -0.95 & $(-1.8,-0.11)$ & $0 \%$ & 0.027 \\
\hline Neut count $\left(10^{\wedge} 9 / \mathrm{L}\right)$ & $3(137)$ & -0.29 & $(-2.91,2.33)$ & $93 \%$ & 0.828 \\
\hline Lymp count $\left(10^{\wedge} 9 / \mathrm{L}\right)$ & $3(137)$ & 0.42 & $(-0.23,1.07)$ & $92.20 \%$ & 0.204 \\
\hline Plt count $\left(10^{\wedge} 10 / \mathrm{L}\right)$ & $3(137)$ & 5.2 & $(-2.85,13.25)$ & $91.40 \%$ & 0.206 \\
\hline $\operatorname{ALT}(\mathrm{U} / \mathrm{L})$ & $3(137)$ & 22.49 & $(-2.73,47.7)$ & $84.80 \%$ & 0.08 \\
\hline $\operatorname{AST}(\mathrm{U} / \mathrm{L}) * * *$ & $3(137)$ & -12.58 & $(-18.88,-6.29)$ & $7.90 \%$ & $<0.001$ \\
\hline Troponin (ng/L) ** & $2(112)$ & 7.61 & $(3.06,12.15)$ & $0 \%$ & 0.001 \\
\hline Creatine (umol/L) & $3(137)$ & -44.78 & $(-93.37,3.81)$ & $79.90 \%$ & 0.071 \\
\hline
\end{tabular}

CI, confidence interval; WMD, weighted mean differences; OR, odds ratio; TCZ, tocilizumab; ST, standard treatment; ICU, intensive care unit; CRP, Creactive protein; WBC, white blood cell; Neut, neutrophil; Lymp, lymphocyte; Plt, platelet; ALT, alanine aminotransferase; AST, aspartate aminotransferase

$* p<0.05 ; * *<0.01 ; * * * p<0.001$

focused on the effectiveness and safety of tocilizumab for treating COVID-19 have not been systemically analyzed.
Therefore, we reviewed and summarized these studies for more accurate conclusions.
Fig. 2 Forest plot of ORs for admission to ICU, use of ventilation, and mortality between TCZ and ST. ICU, intensive care unit; $\mathrm{OR}$, odds ratio; $\mathrm{CI}$, confidence interval

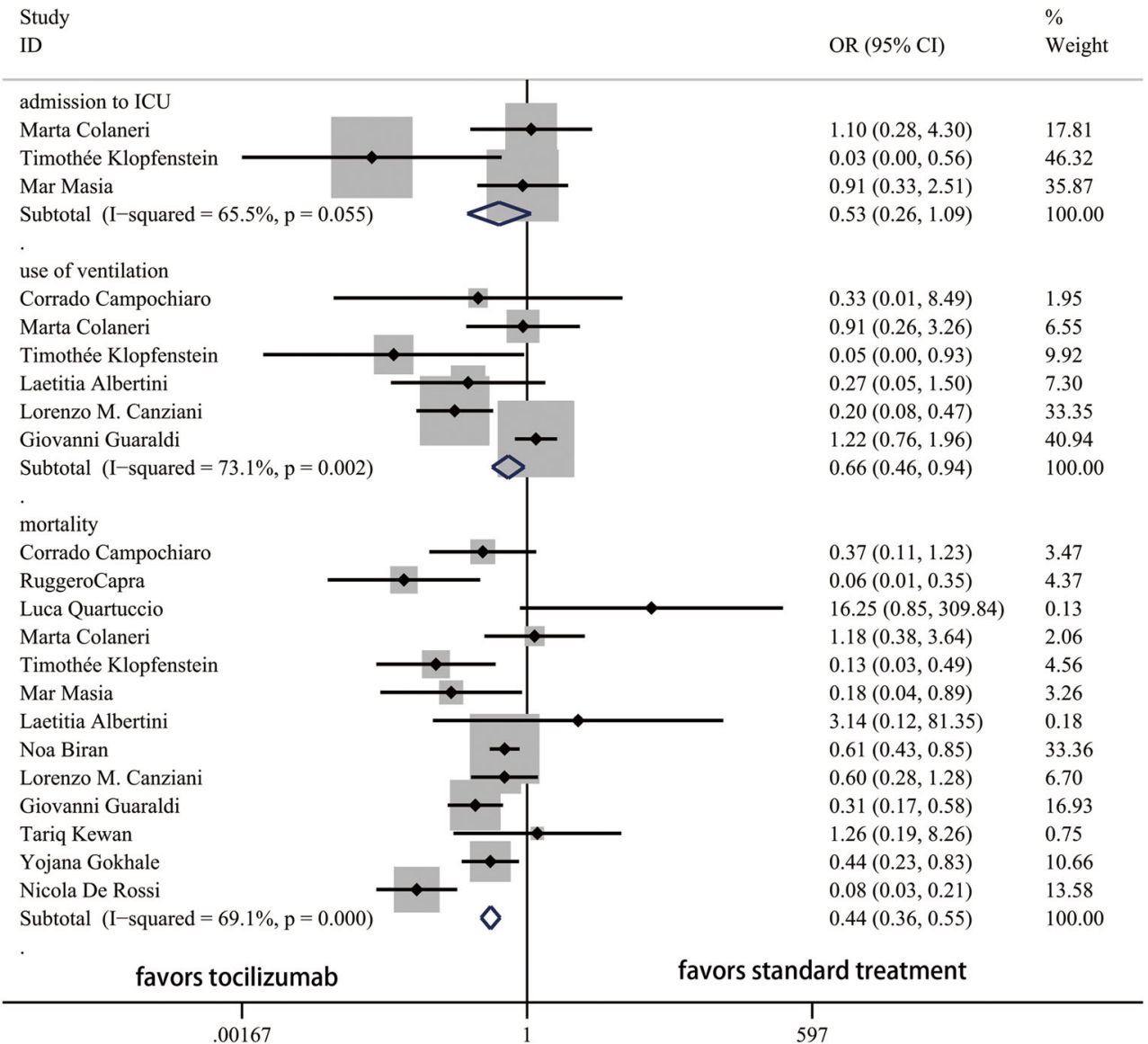


Fig. 3 Forest plot of ORs for clinical improvement between TCZ and ST. OR, odds ratio; CI, confidence interval
Study

ID

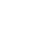

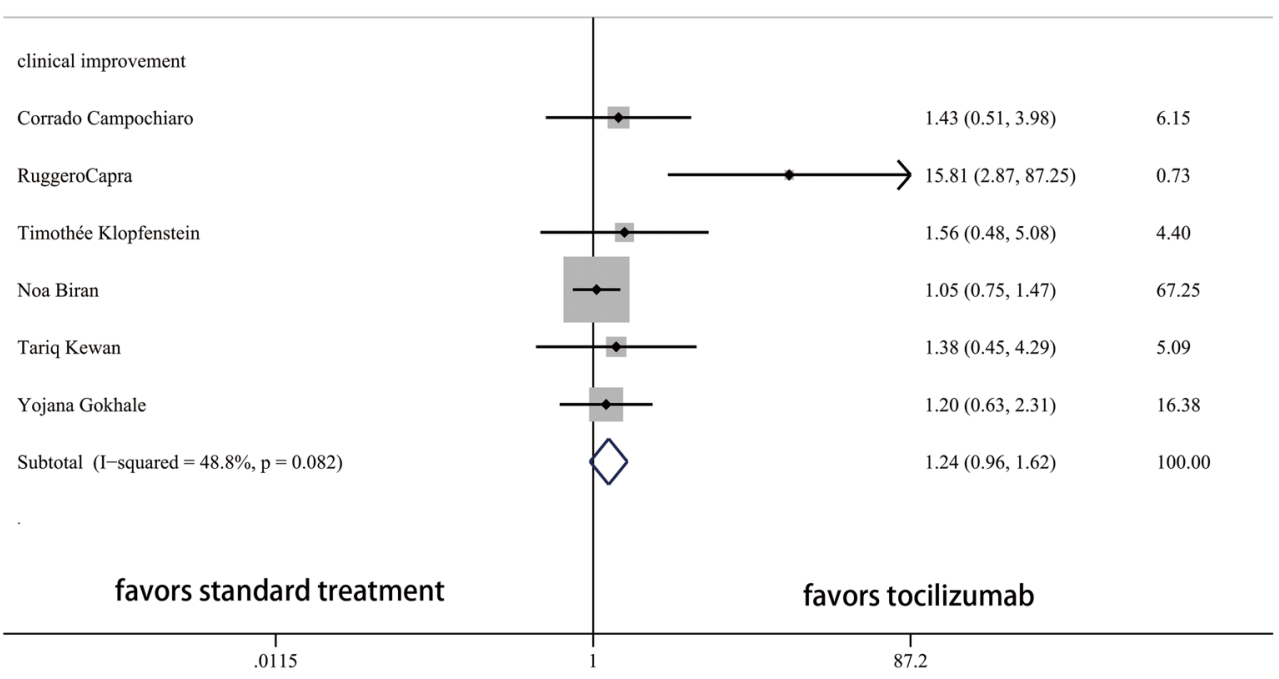

TCZ group have more favorable clinical outcomes compared with the ST group. Lower rate of admission to ICU, use of ventilation, and mortality and higher rate of clinical improvement were identified in this study, which is consistent with the conclusions from the case reports and case series [2-5]. By binding to human IL-6 receptor, tocilizumab competitively inhibits IL-6 signaling [29] and prevents the cytokine storm of patients infected COVID-19. After taking tocilizumab, the serum CRP significantly decreased, which is consistent with the outcomes of treating rheumatoid arthritis, Castleman disease, and Crohn disease [29].

In the blood system, tocilizumab does not have obvious influence on the neutrophil count, lymphocyte count, and platelet count. Despite a significant decrease of WBC was identified after taking tocilizumab, we cannot conclude that tocilizumab has effect on reducing WBC count because of the rarity of high WBC count in patients with COVID-19.

AST was apparently lower than before taking tocilizumab, and ALT was similar with before. A meta-analysis conducted by Mark C. Genovese indicated that transaminase elevations with tocilizumab were frequent [30], which is not consistent with the result of our study. More studies are needed to investigate the effect of tocilizumab on hepatic function. In addition, tocilizumab did not have significant influence on patients' creatine according to the result obtained from this study.
Fig. 4 Forest plot of WMDs for CRP between pre-TCZ and postTCZ. CRP, C-reactive protein; WMD, weighted mean differences; CI, confidence interval

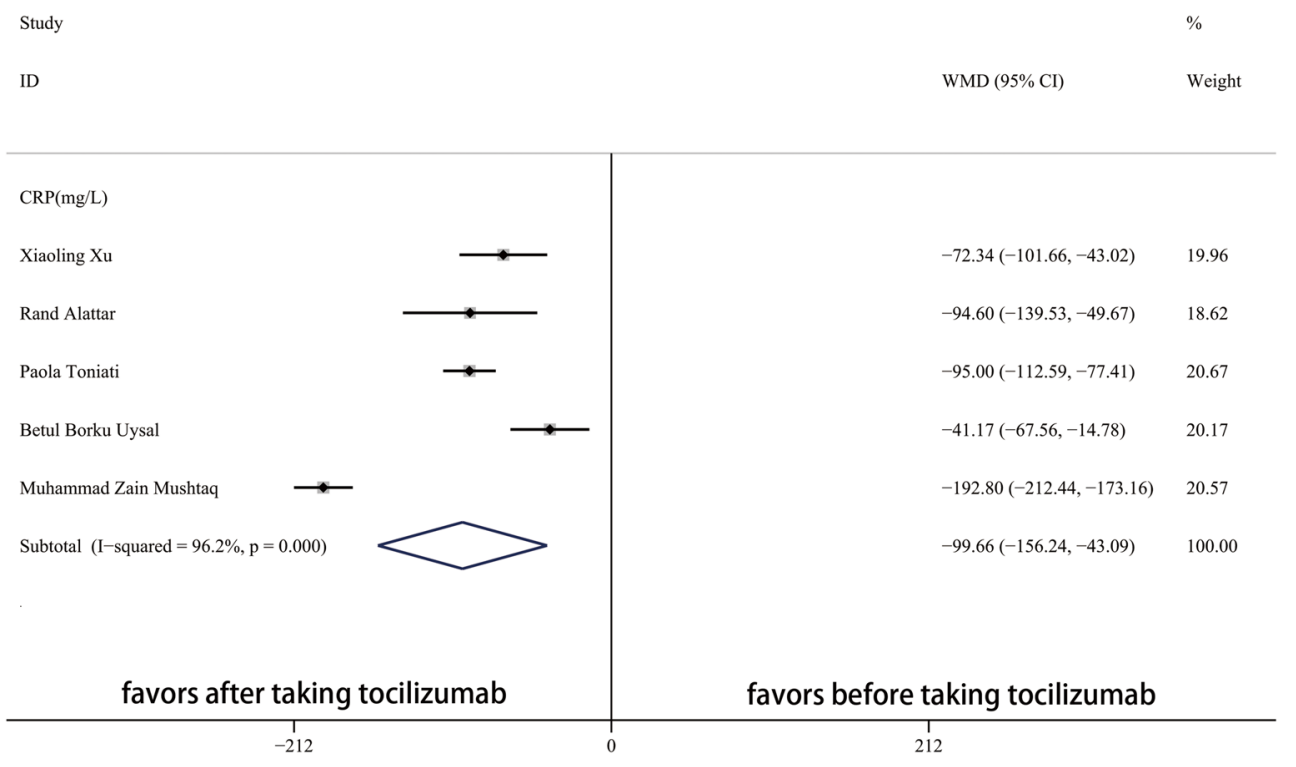


Fig. 5 Forest plot of WMDs for WBC count, Neut count, Lymp count, and Plt count between preTCZ and post-TCZ. WBC, white blood cell; Neut, neutrophil; Lymp, lymphocyte; Plt, platelet; WMD, weighted mean differences; CI, confidence interval
Study

ID

$\%$

WBC $\operatorname{count}\left(* 10^{\wedge} 9 / \mathrm{L}\right)$

Xiaoling Xu

Rand Alattar

Betul Borku Uysal

Subtotal $(\mathrm{I}-$ squared $=0.0 \%, \mathrm{p}=0.874)$

Neut count $\left(* 10^{\wedge} 9 / \mathrm{L}\right)$

Rand Alattar

Paola Toniati

Betul Borku Uysal

Subtotal $(\mathrm{I}-\mathrm{squared}=93.0 \%, \mathrm{p}=0.000)$

Lymp count(*10^9/L)

Rand Alattar

Paola Toniati

Betul Borku Uysal

Subtotal $(\mathrm{I}-\mathrm{squared}=92.2 \%, \mathrm{p}=0.000)$

Plt count $\left(* 10^{\wedge} 10 / \mathrm{L}\right)$

Rand Alattar

Paola Toniati

Betul Borku Uysal

Subtotal $(\mathrm{I}-$ squared $=91.4 \%, \mathrm{p}=0.000)$

values decreased after taking tocilizumab

$-23$
WMD $(95 \%$ CI $) \quad$ Weight

$-1.05(-2.59,0.49) \quad 30.14$

$-1.10(-2.35,0.15) \quad 45.48$

$-0.56(-2.27,1.15) \quad 24.38$

$-0.95(-1.80,-0.11) \quad 100.00$

$-2.00(-3.16,-0.84) \quad 33.49$

$2.20(1.08,3.32) \quad 33.66$

$-1.10(-2.42,0.22) \quad 32.85$

$-0.29(-2.91,2.33) \quad 100.00$

$1.00(0.63,1.37) \quad 33.02$

$0.01(-0.11,0.13) \quad 36.46$

$0.29(-0.20,0.78) \quad 30.52$

$0.42(-0.23,1.07) \quad 100.00$

$-2.30(-6.40,1.80) \quad 33.97$

$2.80(0.35,5.25) \quad 36.01$

$16.56(10.09,23.03) \quad 30.02$

$5.20(-2.85,13.25) \quad 100.00$

values increased after taking tocilizumab
Cardiac injure is common (19.7\%) among hospitalized patients with COVID-19 [31], and cardiac troponin I levels were significantly higher in those with severe COVID-19 infection compared with those with non-severe disease [32]. In this meta-analysis, troponin significantly increased after taking tocilizumab. Whether tocilizumab or the progression of the
Fig. 6 Forest plot of WMDs for ALT, AST, troponin, and creatine between pre-TCZ and post-TCZ. ALT, alanine aminotransferase; AST, aspartate aminotransferase; WMD, weighted mean differences; CI, confidence interval

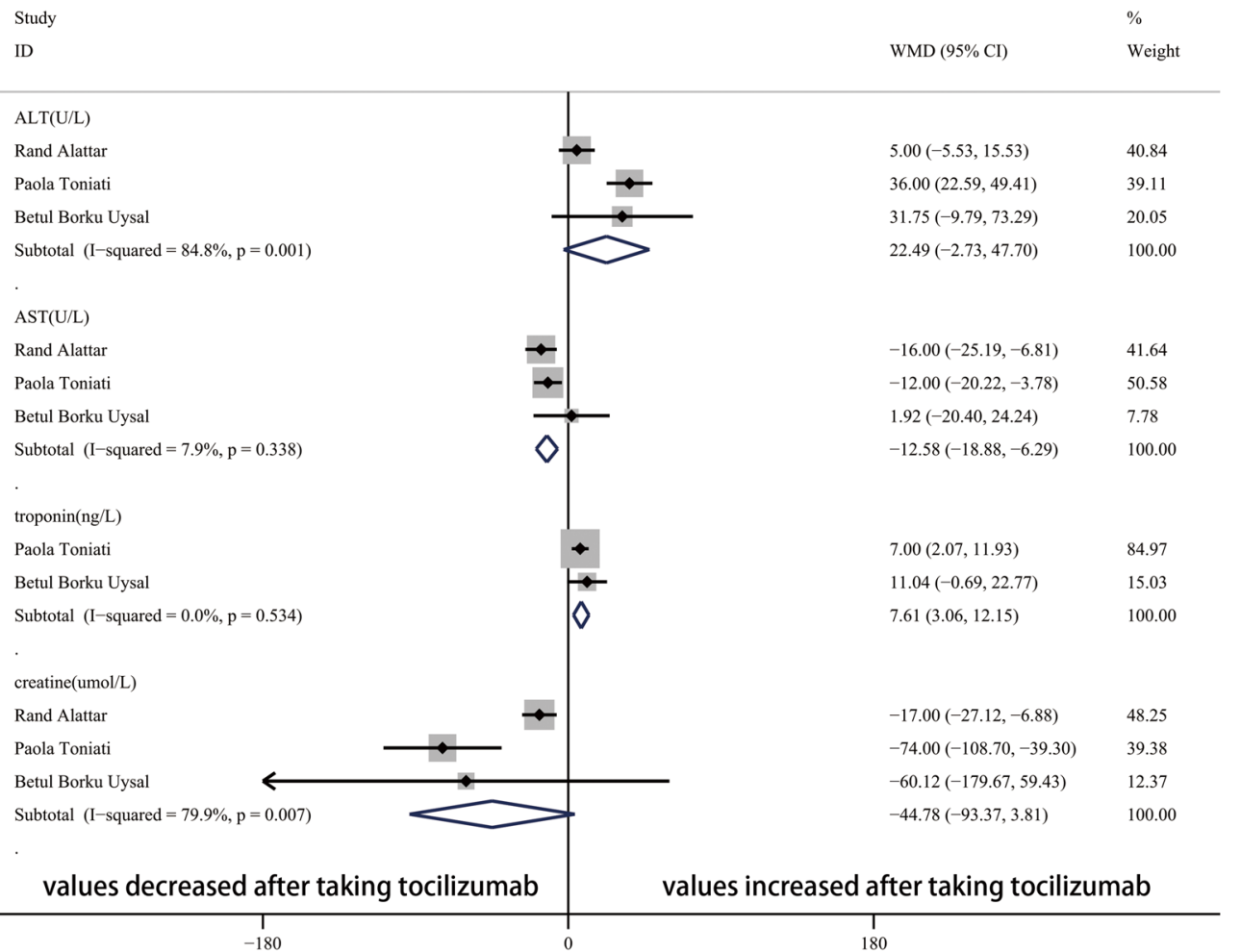


Fig. 7 Sensitivity analysis of studies on mortality between TCZ and ST

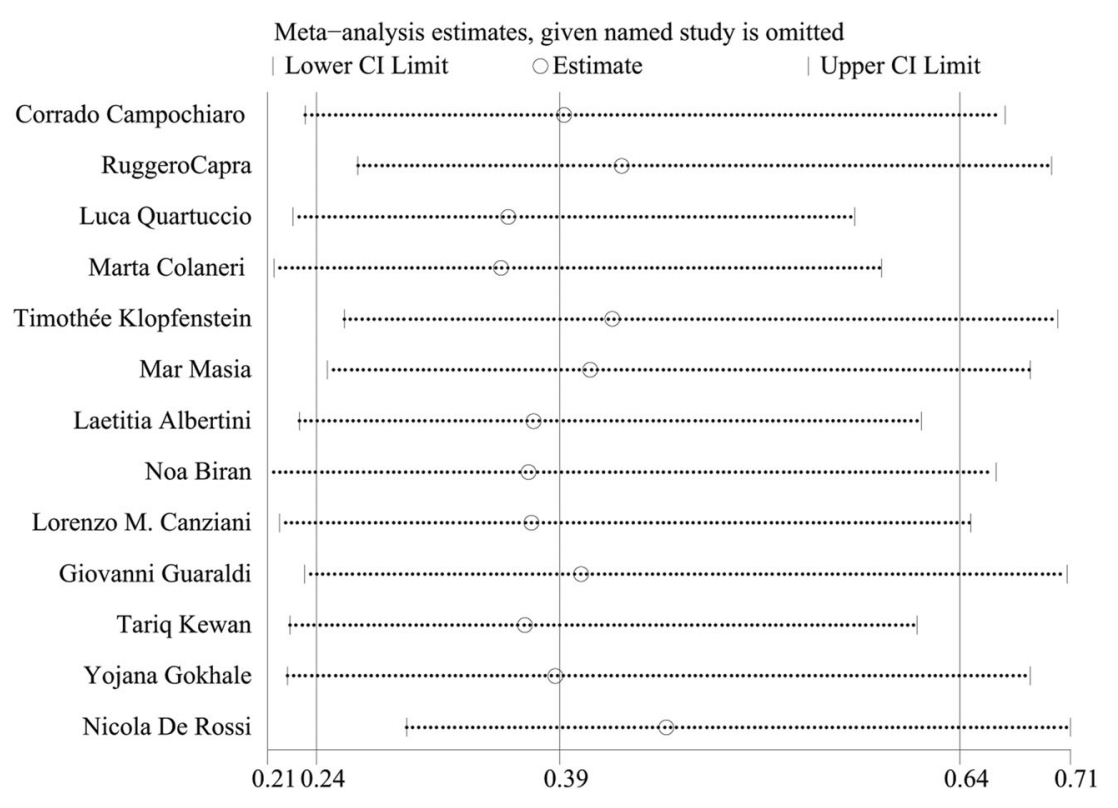

disease caused the elevated troponin remains unclear. More RCTs focused on the comparison of troponin between taking tocilizumab group and no-taking group are needed to figure out whether tocilizumab has cardiac toxicity.

No adverse events after taking tocilizumab were reported in the included studies. But toxic erythema, eosinophilia, and hypertriglyceridemia $[33,34]$ were reported by two case reports after taking tocilizumab. What is more, intestinal perforation should be noticed when using tocilizumab to treat COVID-19 [35].

\section{Limitations}

First, the sample size of this study was extremely small, which results in the high heterogeneities of several observational indicators, low robustness of the results, and low reliability of the conclusion. Second, all the included studies were retrospective observational studies. In retrospective case-control study, it is impossible to match the baseline characteristics of TCZ and ST groups, which may result in severe selection bias. In retrospective singlearmed study, it is difficult to conclude that the improvement or deterioration of the laboratory indexes were caused by the effect of tocilizumab or the progression of the disease itself because of the absence of the control group. Third, in the situation of COVID-19 pandemic with no specific therapy drug available, studies with positive conclusions are more easily to be published, which may result in obvious publication bias. Although publication bias was not assessed because of the limited number of included studies, it does not mean there is no publication bias in this meta-analysis. Fourth, the data of each included study is insufficient.

\section{Conclusion}

Tocilizumab may have potential effectiveness to treat COVID-19 according to the results of this study. However, more large-scale studies are needed for more accurate conclusions because of the limited sample size of this study.

Acknowledgments The authors thank Dr. Zhong Yuan and Huang Haobin for the assistance with this study.

Authors' contributions MZ and JYL collected and analyzed the data and wrote the paper; YHT and YWD collected and analyzed the data; JXZ and YHW revised the whole paper. All authors reviewed the final paper. All authors read and approved the final manuscript.

Funding This work was financially supported by projects of the National Youth Foundation of China (NSFC, grant nos. 81700340).

\section{Compliance with ethical standards}

Conflict of interest The authors declare that they have no conflict of interest.

\section{References}

1. Guan WJ, Ni ZY, Hu Y, Liang WH, Ou CQ, He JX, Liu L, Shan H, Lei CL, Hui DSC, du B, Li LJ, Zeng G, Yuen KY, Chen RC, Tang CL, Wang T, Chen PY, Xiang J, Li SY, Wang JL, Liang ZJ, Peng YX, Wei L, Liu Y, Hu YH, Peng P, Wang JM, Liu JY, Chen Z, Li G, Zheng ZJ, Qiu SQ, Luo J, Ye CJ, Zhu SY, Zhong NS, China Medical Treatment Expert Group for Covid-19 (2020) Clinical characteristics of coronavirus disease 2019 in China. N Engl J Med 382(18):1708-1720. https://doi.org/10.1056/ NEJMoa2002032

2. De Luna G, Habibi A, Deux JF et al (2020) Rapid and severe Covid-19 pneumonia with severe acute chest syndrome in a sickle 
cell patient successfully treated with tocilizumab. Am J Hematol 95(7):876-878. https://doi.org/10.1002/ajh.25833

3. Michot JM, Albiges L, Chaput N, Saada V, Pommeret F, Griscelli F, Balleyguier C, Besse B, Marabelle A, Netzer F, Merad M, Robert C, Barlesi F, Gachot B, Stoclin A (2020) Tocilizumab, an anti-IL-6 receptor antibody, to treat COVID-19-related respiratory failure: a case report. Ann Oncol 31(7):961-964. https://doi.org/10.1016/j. annonc.2020.03.300

4. Lauterio A, Valsecchi M, Santambrogio S et al (2020) Successful recovery from severe COVID-19 pneumonia after kidney transplantation: The interplay between immunosuppression and novel therapy including tocilizumab [published online ahead of print, 2020 May 25]. Transpl Infect Dis:e13334. https://doi.org/10. 1111/tid.13334

5. Odièvre MH, de Marcellus C, Ducou Le Pointe H, et al. Dramatic improvement after tocilizumab of severe COVID-19 in a child with sickle cell disease and acute chest syndrome. Am J Hematol 2020;95(8):E192-E194. https://doi.org/10.1002/ajh.25855

6. Yang L, Wang G, Du Y, Ji B, Zheng Z (2014) Remote ischemic preconditioning reduces cardiac troponin I release in cardiac surgery: a meta-analysis. J Cardiothorac Vasc Anesth 28(3):682-689. https://doi.org/10.1053/j.jvca.2013.05.035

7. Campochiaro C, Della-Torre E, Cavalli G, de Luca G, Ripa M, Boffini N, Tomelleri A, Baldissera E, Rovere-Querini P, Ruggeri A, Monti G, de Cobelli F, Zangrillo A, Tresoldi M, Castagna A, Dagna L, TOCI-RAF Study Group, Angelillo P, Assanelli A, Baldissera E, Boffini N, Calvisi S, Campochiaro C, Canetti D, Cariddi A, Castagna A, Cavalli G, Ciceri F, Dagna L, de Cobelli F, de Luca G, Torre ED, Farina N, Fazio M, Landoni G, Mancuso G, Marinosci A, Monti G, Oltolini C, Ripa M, Rovere-Querini P, Ruggeri A, Sartorelli S, Scarpellini P, Spessot M, Tomelleri A, Tresoldi M, Zangrillo A (2020) Efficacy and safety of tocilizumab in severe COVID-19 patients: a single-centre retrospective cohort study. Eur J Intern Med 76:43-49. https://doi.org/10.1016/j.ejim. 2020.05.021

8. Capra R, De Rossi N, Mattioli F et al (2020) Impact of low dose tocilizumab on mortality rate in patients with COVID-19 related pneumonia. Eur J Intern Med 76:31-35. https://doi.org/10.1016/j. ejim.2020.05.009

9. Quartuccio L, Sonaglia A, McGonagle D, Fabris M, Peghin M, Pecori D, de Monte A, Bove T, Curcio F, Bassi F, de Vita S, Tascini C Profiling COVID-19 pneumonia progressing into the cytokine storm syndrome: results from a single Italian centre study on tocilizumab versus standard of care [published online ahead of print, 2020 May 15]. J Clin Virol 2020;129:104444. https://doi.org/ 10.1016/j.jcv.2020.104444

10. Colaneri M, Bogliolo L, Valsecchi P et al (2020) Tocilizumab for treatment of severe COVID-19 patients: preliminary results from SMAtteo COvid19 REgistry (SMACORE). Microorganisms 8(5): 695. Published 2020 May 9. https://doi.org/10.3390/ microorganisms 8050695

11. Klopfenstein T, Zayet S, Lohse A et al (2020) Tocilizumab therapy reduced intensive care unit admissions and/or mortality in COVID19 patients [published online ahead of print, 2020 May 6]. Med Mal Infect S0399-077X(20):30129-30123. https://doi.org/10.1016/j. medmal.2020.05.001

12. Masiá M, Fernández-González M, Padilla S, Ortega P, García JA, Agulló V, García-Abellán J, Telenti G, Guillén L, Gutiérrez F (2020) Impact of interleukin-6 blockade with tocilizumab on SARS-CoV-2 viral kinetics and antibody responses in patients with COVID-19: a prospective cohort study. EBioMedicine 60:102999. https://doi.org/10.1016/j.ebiom.2020.102999 Epub ahead of print

13. Albertini L, Soletchnik M, Razurel A, Cohen J, Bidegain F, Fauvelle F, Safrano G, Piquet J, Maurer C, Goldgran-Toledano D (2020) Observational study on off-label use of tocilizumab in patients with severe COVID-19. Eur J Hosp Pharm. 10:ejhpharm-
2020-002414. https://doi.org/10.1136/ejhpharm-2020-002414. Epub ahead of print

14. Biran N, Ip A, Ahn J, Go RC, Wang S, Mathura S, Sinclaire BA, Bednarz U, Marafelias M, Hansen E, Siegel DS, Goy AH, Pecora AL, Sawczuk IS, Koniaris LS, Simwenyi M, Varga DW, Tank LK, Stein AA, Allusson V, Lin GS, Oser WF, Tuma RA, Reichman J, Brusco L Jr, Carpenter KL, Costanzo EJ, Vivona V, Goldberg SL (2020) Tocilizumab among patients with COVID-19 in the intensive care unit: a multicentre observational study. Lancet Rheumatol 2(10):e603-e612. https://doi.org/10.1016/S2665-9913(20)30277-0

15. Guaraldi G, Meschiari M, Cozzi-Lepri A, Milic J, Tonelli R, Menozzi M, Franceschini E, Cuomo G, Orlando G, Borghi V, Santoro A, Di Gaetano M, Puzzolante C, Carli F, Bedini A, Corradi L, Fantini R, Castaniere I, Tabbì L, Girardis M, Tedeschi S, Giannella M, Bartoletti M, Pascale R, Dolci G, Brugioni L, Pietrangelo A, Cossarizza A, Pea F, Clini E, Salvarani C, Massari M, Viale PL, Mussini C (2020) Tocilizumab in patients with severe COVID-19: a retrospective cohort study. Lancet Rheumatol 2(8): e474-e484. https://doi.org/10.1016/S2665-9913(20)30173-9 Epub 2020 Jun 24. Erratum in: Lancet Rheumatol. 2020 Oct;2(10):e591. PMID: 32835257; PMCID: PMC7314456

16. Kewan T, Covut F, Al-Jaghbeer MJ, Rose L, Gopalakrishna KV, Akbik B (2020) Tocilizumab for treatment of patients with severe COVID-19: A retrospective cohort study. EClinicalMedicine 24: 100418. https://doi.org/10.1016/j.eclinm.2020.100418

17. Canziani LM, Trovati S, Brunetta E, Testa A, De Santis M, Bombardieri E, Guidelli G, Albano G, Folci M, Squadroni M, Beretta GD, Ciccarelli M, Castoldi M, Lleo A, Aghemo A, Vernile L, Malesci A, Omodei P, Angelini C, Badalamenti S, Cecconi M, Cremonesi A, Selmi C (2020) Humanitas and Gavazzeni / Castelli COVID-19 Task Forces. Interleukin-6 receptor blocking with intravenous tocilizumab in COVID-19 severe acute respiratory distress syndrome: a retrospective case-control survival analysis of 128 patients. J Autoimmun 8:102511. https://doi.org/ 10.1016/j.jaut.2020.102511

18. Gokhale Y, Mehta R, Karnik N, Kulkarni U, Gokhale S (2020) Tocilizumab improves survival in patients with persistent hypoxia in severe COVID-19 pneumonia. EClinicalMedicine 24:100467. https://doi.org/10.1016/j.eclinm.2020.100467

19. De Rossi N, Scarpazza C, Filippini C, Cordioli C, Rasia S, Mancinelli CR, Rizzoni D, Romanelli G, Cossi S, Vettoretto N, Bove S, Manfredini S, Beindorf EA, Mosca C, Scipione V, Flamminio G, Albini EA, Giansiracusa P, Capra R (2020) Montichiari COVID-19 Study Group. Early use of low dose tocilizumab in patients with COVID-19: A retrospective cohort study with a complete follow-up. EClinicalMedicine 25:100459. https:// doi.org/10.1016/j.eclinm.2020.100459

20. Xu X, Han M, Li T, Sun W, Wang D, Fu B, Zhou Y, Zheng X, Yang Y, Li X, Zhang X, Pan A, Wei H (2020) Effective treatment of severe COVID-19 patients with tocilizumab. Proc Natl Acad Sci U S A 117(20):10970-10975. https://doi.org/10.1073/pnas. 2005615117

21. Issa N, Dumery M, Guisset O, Mourissoux G, Bonnet F, Camou F (2020) Feasibility of Tocilizumab in ICU patients with COVID-19 [published online ahead of print, 2020 Jun 2]. J Med Virol. https:// doi.org/10.1002/jmv. 26110

22. Alattar R, Ibrahim TBH, Shaar SH et al (2020) Tocilizumab for the treatment of severe coronavirus disease 2019 [published online ahead of print, 2020 May 5]. J Med Virol. https://doi.org/10.1002/ jmv. 25964

23. Toniati P, Piva S, Cattalini M, Garrafa E, Regola F, Castelli F, Franceschini F, Airò P, Bazzani C, Beindorf EA, Berlendis M, Bezzi M, Bossini N, Castellano M, Cattaneo S, Cavazzana I, Contessi GB, Crippa M, Delbarba A, de Peri E, Faletti A, Filippini M, Filippini M, Frassi M, Gaggiotti M, Gorla R, Lanspa M, Lorenzotti S, Marino R, Maroldi R, Metra M, Matteelli A, 
Modina D, Moioli G, Montani G, Muiesan ML, Odolini S, Peli E, Pesenti S, Pezzoli MC, Pirola I, Pozzi A, Proto A, Rasulo FA, Renisi G, Ricci C, Rizzoni D, Romanelli G, Rossi M, Salvetti M, Scolari F, Signorini L, Taglietti M, Tomasoni G, Tomasoni LR, Turla $\mathrm{F}$, Valsecchi A, Zani D, Zuccalà $\mathrm{F}$, Zunica $\mathrm{F}$, Focà $\mathrm{E}$, Andreoli L, Latronico N (2020) Tocilizumab for the treatment of severe COVID-19 pneumonia with hyperinflammatory syndrome and acute respiratory failure: a single center study of 100 patients in Brescia, Italy. Autoimmun Rev 19(7):102568. https://doi.org/10. 1016/j.autrev.2020.102568

24. Borku Uysal B, Ikitimur H, Yavuzer S et al (2020) Tocilizumab challenge: a series of cytokine storm therapy experiences in hospitalized COVID-19 pneumonia patients [published online ahead of print, 2020 Jun 2]. J Med Virol. https://doi.org/10.1002/jmv.26111, https://doi.org/10.1002/jmv.26111

25. Zain Mushtaq M, Bin Zafar Mahmood S, Jamil B, Aziz A, Ali SA (2020) Outcome of COVID-19 patients with use of tocilizumab: a single center experience. Int Immunopharmacol 88:106926. https:// doi.org/10.1016/j.intimp.2020.106926

26. Huang C, Wang Y, Li X, Ren L, Zhao J, Hu Y, Zhang L, Fan G, Xu J, Gu X, Cheng Z, Yu T, Xia J, Wei Y, Wu W, Xie X, Yin W, Li H, Liu M, Xiao Y, Gao H, Guo L, Xie J, Wang G, Jiang R, Gao Z, Jin Q, Wang J, Cao B (2020) Clinical features of patients infected with 2019 novel coronavirus in Wuhan, China [published correction appears in lancet. 2020 Jan 30;]. Lancet. 395(10223):497-506. https://doi.org/10.1016/S0140-6736(20)30183-5

27. Wang D, Hu B, Hu C, Zhu F, Liu X, Zhang J, Wang B, Xiang H, Cheng Z, Xiong Y, Zhao Y, Li Y, Wang X, Peng Z (2020) Clinical characteristics of 138 hospitalized patients with 2019 novel coronavirus-infected pneumonia in Wuhan, China [published online ahead of print, 2020 Feb 7]. JAMA. 323(11):1061-1069. https://doi.org/10.1001/jama.2020.1585

28. Zhou F, Yu T, Du R et al (2020) Clinical course and risk factors for mortality of adult inpatients with COVID-19 in Wuhan, China: a retrospective cohort study [published correction appears in Lancet. 2020 Mar 28;395(10229):1038] [published correction appears in Lancet. 2020 Mar 28;395(10229):1038]. Lancet. 395(10229): 1054-1062. https://doi.org/10.1016/S0140-6736(20)30566-3
29. Nishimoto N, Terao K, Mima T, Nakahara H, Takagi N, Kakehi T (2008) Mechanisms and pathologic significances in increase in serum interleukin-6 (IL-6) and soluble IL-6 receptor after administration of an anti-IL-6 receptor antibody, tocilizumab, in patients with rheumatoid arthritis and Castleman disease. Blood. 112(10):3959 3964. https://doi.org/10.1182/blood-2008-05-155846

30. Genovese MC, Kremer JM, van Vollenhoven RF, Alten R, Scali JJ, Kelman A, Dimonaco S, Brockwell L (2017) Transaminase levels and hepatic events during tocilizumab treatment: pooled analysis of long-term clinical trial safety data in rheumatoid arthritis. Arthritis Rheum 69(9):1751-1761. https://doi.org/10.1002/art.40176

31. Shi S, Qin M, Shen B, Cai Y, Liu T, Yang F, Gong W, Liu X, Liang J, Zhao Q, Huang H, Yang B, Huang C (2020) Association of cardiac injury with mortality in hospitalized patients with COVID-19 in Wuhan, China [published online ahead of print, 2020 Mar 25]. JAMA Cardiol 5(7):802-810. https://doi.org/10. 1001/jamacardio.2020.0950

32. Lippi G, Lavie CJ, Sanchis-Gomar F (2020) Cardiac troponin I in patients with coronavirus disease 2019 (COVID-19): evidence from a meta-analysis [published online ahead of print, 2020 Mar 10]. Prog Cardiovasc Dis. https://doi.org/10.1016/j.pcad.2020.03.001

33. Sernicola A, Carnicelli G, Di Fraia M et al (2020) Toxic erythema' and eosinophilia associated with tocilizumab therapy in a COVID19 patient [published online ahead of print, 2020 May 9]. J Eur Acad Dermatol Venereol. https://doi.org/10.1111/jdv.16620, https://doi.org/10.1111/jdv.16620

34. Morrison AR, Johnson JM, Ramesh M, Bradley P, Jennings J, Smith ZR (2020) Acute hypertriglyceridemia in patients with COVID-19 receiving tocilizumab [published online ahead of print, 2020 Apr 21]. J Med Virol. https://doi.org/10.1002/jmv.25907, https://doi.org/10.1002/jmv.25907

35. Vikse J, Henry BM. Tocilizumab in COVID-19: beware the risk of intestinal perforation [published online ahead of print, 2020 May 7]. Int J Antimicrob Agents 2020;106009. https://doi.org/10.1016/j. ijantimicag.2020.106009

Publisher's note Springer Nature remains neutral with regard to jurisdictional claims in published maps and institutional affiliations. 